\title{
USING THREE PHASE TECHNIQUE WITH VOCABULARY QUIZ AS A PRE ACTIVITY TO IMPROVE STUDENTS' READING PERFORMANCE
}

\author{
Amroji \\ SMPN 2 Gondanglegi \\ amroji435@gmail.com
}

\begin{abstract}
The objective of the study is to find out how to use three phase technique with vocabulary quiz as a pre activity to improve students' reading performance, specifically, their reading motivation and comprehension achievement. This was a classroom action research and there were two cycles in this study. The procedures, which covers four main phases: the vocabulary quiz, the pre, whilst and post reading activities, had fulfilled the criteria of success in this study. This fact was clearly shown by the increase of students' reading motivation as indicated by their learning orientation in reading class. They were at least externally imposed to the rules that they accepted as norms to follow so as not to feel guilty. Their attitudes and behaviors toward reading class were as good as expected by the criteria of success in this study. The students' reading comprehension achievement was also improved to 66.73 as their average score of reading comprehension test had gained the minimal passing grade expected by the school curriculum that was 65 . So, in this study, it can be concluded that this strategy can improve students' reading performance and can possibly get better result for the future study if they are applied more deliberately and effectively.
\end{abstract}

Keywords: three phase technique, vocabulary quiz, reading performance.

\section{INTRODUCTION}

In the level of SMP (Junior High School), the goal of learning English is developing students' communicative competence with the focus on the language skills to be learned i.e. listening, speaking, reading and writing (Agustien, 2006:34). Among those skills, reading is the most important one that needs more attention in the teaching and learning activity. In the language classroom, reading is taught most compared to other language skills. Most English tests are also in the form of reading. The test of UN (National Exam), for instance, is primarily about reading besides a few items of writing.

Although reading dominates more than the other three language skills, the result of students' reading test is not good, not to the level of what the English teachers expect. The data on the result of the students' semester tests at SMPN 2 Gondanglegi for the last three years, mostly about reading tests, showed that the their average scores were not fulfilled the minimum criteria of the passing grade which was 65 . It is clear that they fail to achieve the expected comprehension achievement for English subject. Furthermore, exposures around the students' reading environment also do not support their motivation to read so that it is hard to find our students willingly read books with their own self-motivation.

The unsatisfactory result of students' reading comprehension regarding English reading tests and their low motivation to read might be caused by some problems. Most of the English learners (especially beginners), including the SMP students, claim that vocabularies are the most crucial component in learning English especially reading. Baradja (1990:115) asked a group of students about why a text was difficult to understand. All of them accused the vocabularies in the text as the main cause of the problem. It means that they cannot catch the content of the text because they do not even recognize some of the words in the text. 
Some studies on the relationship between reading comprehension and vocabulary knowledge have long been recognized. One of the study by Hudson (2007:227) indicated that "vocabulary is a considerable factor in reading ability. Consequently, it appears that a large vocabulary can facilitate reading comprehension." It can be understood that when a reader reads a text, he employs "his" vocabularies knowledge to get the intended message from the text. The more he has mastered the vocabulary, the better he gets the message of the text.

Somehow, it is not that simple to overcome reading problems by only developing their vocabulary mastery since there are other factors to be considered. Mathison (1989) and and Kweldju (1994) said that factors such as poor reading strategies and low interest on the topics, or motivation to read a certain text, may account for some aspects of the problem.

Mathison (1989:171) stated that "the focus of instruction needs to include an emphasis on the factors that motivate students to read their textbooks as well as factors that enhance reading ability." It means that the developing students' vocabulary in the teaching of reading needs involving their motivation and strategy as well. Kweldju (1994:42) added that motivation is one such effective factor crucial to successful textbook reading. Poor motivation may cause even the most able reader not to read a required textbook. High motivation, on the other hand, energizes readers to continually interact with the text. Highly motivated readers tend to involve themselves in on-going process of interpreting and assimilating the author's main idea within the framework of their own prior knowledge and experience. Teachers need to learn to manipulate this factor to promote student learning.

As observed during the writer's many years of teaching at SMPN 2 Gondanglegi, especially when students were given preliminary reading tests at daily tests, he found out that the students' reading skill was low. Their comprehension was not sufficient and their vocabulary mastery was poor. They commonly scored low in the reading comprehension test in the ninth grade where the writer taught them for the first time. From the twice preliminary reading tests, it was found that the lowest score was 31 while the highest was 94, and the average score was 52.69. So, the students' average score here is quite far from the minimum passing grade for English subject which is 65 based on the KTSP SMPN 2 Gondanglegi.

Furthermore, these students were not adequately exposed to English passages unless the teachers provided the texts. It seems that their motivation to read was low. From the pre research questionnaire of this study, it was found out that most of the students (65.91) just sometimes read English texts from the textbook. This condition may be caused by the fact that students always found difficulties in comprehending texts and their internal orientation toward English was relatively low. The possible causes are that they have limited vocabulary mastery, and they have no idea to read effectively.

In this study, the researcher used the three phase technique which is one of the very common strategies of reading comprehension class used by teachers with a slight modification of the strategy. Sugiono (2000) maximized the use vocabulary instructions within a reading comprehension course. Some of the activities in the pre, during and after reading phases were pre teaching vocabulary, pre test, pictures use, memorizing, etc. In every activity, he focused more on students' vocabulary learning to increase their vocabulary mastery in order that sufficient vocabulary could lead to a better skill of reading comprehension. In fact, there were $92.31 \%$ out of 39 students stated that the memorizing activity could improve their vocabulary which would then lead them to a better reading comprehension. So, the use of the three phase technique with the focus on the vocabulary 
learning had been successfiully proven to improve reading comprehension in such a way by the previous researcher; while, this study has also a goal to improve reading motivation.

However, in the real teaching and learning practice, it is often found that teachers encounter gaps between theory and practice. In teaching reading (Sugiono, 2000), the three phase technique which consists of pre, whilst, and post reading, can be theoretically conducted with the focus on vocabulary learning in every phase. Somehow, in the writer's class, it is not quite practical to achieve the reading learning objectives. It takes more time, and the focus of the learning can be slightly mislead. Therefore, teachers should develop their own personal ideas from their own class practices. One of the ways to develop these personal ideas is by conducting an action research since this approach is a unified exercise that sees a teacher as the best judge of student's total education experience, and it is a powerful method of bridging the gap between the theories and practice on education (Mc. Niff in Hanafi, 2004:3).

Based on the facts above, the writer conducts this classroom action research, assisted by an English teacher as an observer. The aim of the study is to find the answer of how to use three phase technique with vocabulary quiz as pre activity to improve the students' reading performance.

\section{METHOD}

\section{Setting}

The subjects of this research were the third-year students of SMPN 2 Gondanglegi, class IX A. This school is located in Sukorejo, a village in Gondanglegi town, about 25 kilometers from the city of Malang. The people in the village work as farmers, farming/building labors and most preferably unskilled labors abroad.

During this study, from the end of September until the early of November 2019, there were 26 students in this class. These students have studied English for two years in the early classes of Junior High School. During the years, they were imposed to English class twice a week which was aproximately 2 x 90 minutes.

\section{Preliminary Study and the Reasearch Preparation}

To know the students' competence in reading comprehension before implementing the action research, the researcher administered a test. The test was held after a regular teaching and learning process. The material of the test was taken from the book entitled "Genre" (Djuharie, 2007:133). The competences tested in the pre test covered four comprehension questions, i.e. finding: main ideas, stated information, implied information, and also references of a word/s in a text. Each of which consisted of two items so that there were eight questions. The result of the test showed that the students' current reading achievement was low. It was found that the lowest score was 31 while the highest was 94, and the average score was 52.69.

From the fact-findings analysis phase related to their motivation in reading, it was found some problems which seemed to be categorized as amotivation. Students did not have a good preparation when they came in to the class. Some of them did not bring their notebooks and textbooks. Some of them did not do their homework when the teacher checked it. Some of them even had no ideas about what material to be learnt in the current meeting since they 
did not know what pages they had been through so far in the textbook. These facts revealed the real condition of the students' low motivation to learn English.

\section{The Procedures of the Three Phase Technique with Vocabulary Quiz as a Pre Activity}

The three phase technique with vocabulary quiz as a pre activity in reading comprehension class includes four main phases, i.e. pre activity, where the vocabulary quiz is conducted, pre reading, whilst reading, and post reading. The pre activity phase, where the vocabulary quiz is implemented, includes activities i.e. instructing students firmly to prepare for the quiz (reading a pre determined text, making vocabulary notes based on the text and memorizing them), checking the students' readiness for the quiz and the reading class (checking their vocabulary notes on their notebooks, and the availability of the text books, paper and pens). In addition, the teacher also has to prepare two sets of quiz items so that each student in one desk would have different quiz items. Then, s/he must read out clearly those vocabularies to be written and given the meanings by the students. Finally, the teacher collects and scores the students" work as "rewards"

In the pre reading phase, the teacher initiates and activates students' prior knowledge by presenting some teaching media and asking some initial classroom questions related to the theme. The students are expected to response and answer the teacher's initial questions. In this phase, the teacher has to make sure that the students are really aware to the theme being discussed in the meeting by asking a confirmation question or just writing it on the board.

Next, in whilst reading, the students are given the opportunities to interact more with the text in some reading skill activities such as skimming and scanning the text for identifying general and detail information. Besides, other activities to develop students' reading skills are also possibly presented here for example: mind mapping a text to classify main ideas and the supporting ideas of the text and also to determine word/s references, or summarizing a text to simplify general ideas, supporting ideas and even implied ideas. To train the students' logical thinking toward the sequence of the text, we can also use an activity of matching pictures to their descriptions. It is also important here to present different kinds of challenging tasks of reading comprehension skills which would also activate the students' interaction with the texts.

In the final phase, the post reading, students are given comprehension questions to be answered individually to consolidate their new knowledge based on their previous learning experience in the whilst reading phase. Furthermore, these questions are also used as an instrument of measuring students' comprehension achievement.

\section{Planning the Reasearch}

Before implementing the real action research, the researcher ensured the planning of the cycles of the action reasearch by designing the lesson plans, preparing the materials, and preparing the criteria of success.

The complete procedures of the action research in the lessson plan were described as follows:

The pre activity phase, the vocabulary quiz was included, covered the following activities:

(1) opening the class which includes checking the students' attendance; 
(2) preparing a number of vocabularies (related to the topic) to be tested;

(3) preparing students' readiness to have the quiz, i.e. asking the students whether they have read the text and prepared a piece of paper;

(4) explaining the rule of the quiz, i.e. asking the students to write the vocabularies that the teacher reads out and then giving their translations;

(5) reading out loud each vocabulary one after another to be written by the students and given their translations in Indonesian (approximately 5 to 8 vocabularies for each text);

(6) collecting students' answers sheet to be scored after the class period is over.

The pre-reading phase included the following activities:

(1) introducing the topic by either using pictures or questions related to the selected text;

(2) relating the text or picture to student's life by asking them things related to their life;

(3) asking the groups to predict the topic from the title or the pictures related to the text;

(4) writing vocabularies related to the topic.

The whilst reading phase included the activities as follows:

(1) asking the students to read the text silently;

(2) asking students to listen to the teacher or other student reads the text;

(3) presenting a table to be completed with information from the text, or giving an example of making an outline/a summary from a text, or initiating a mind mapping of a text, etc.;

(4) discussing the result of students' works on table completion, an outline/a summary making or mind mapping;

(5) presenting some comprehension questions in oral or written form related to the text (questions about main ideas, stated/implied information, or a word/s reference);

(4) asking students to answer the questions (short or long, open ended answers are accepted);

(5) asking some students to write the answers of the questions on the board;

(6) discussing the answers with the class;

(7) asking students about the conclusion.

The post-reading phase encompasses the following activities:

(1) checking individual student's comprehension by giving comprehension questions to be answered based on the previous text, or;

(2) presenting another text (unseen) with the same topic to be read by the students silently; 
(3) presenting 10 comprehension questions in written form related to the text;

(4) collecting students' answers sheet;

(5) scoring their answers;

(6) closing the meeting.

In whilst reading phase, the students-centered reading activity was planned to go deeper into the text. Mind mapping, completing a table, and summarizing or outlining a text were some of the students' activities while the teacher was observing the learning atmosphere and facilitating the students' work in this phase.

Finally, answering some comprehension questions was asked to the students to be last phase of the reading activity (post reading). The students' answers in their work books were reviewed and checked together with the whole class at the end of the class session. The scores were given to those students' works to be quantitative data for the researcher.

In the second cycle, changes were added to the procedures above. Grouping students into two (A and B) in the vocabulary quiz while the teacher prepares two sets of vocabularies for the quiz was one of the modifications. Another was the selection of the texts to be tested in the post reading phase. In the first cycle, the texts used as the comprehension tests was the same texts as the ones used in whilst reading phase; however, in the second cycle, the texts were unseen ones.

Beside the lesson plan, the teacher also prepared the material for this study. This material contained texts with exercises on comprehension questions for Junior High School students. They were simple texts of approximately 100-150 words in length with vocabulary level of SMP students. The materials were taken from a book entitled "Real Time 3" (Bates, 2005). The foremost goal of the text was to provide students with materials for a vocabulary quiz given as a pre activity of a reading comprehension class. The vocabularies (especially concerning with the themes) were supposed to be mastered by the students before the reading class begins. The questions applied to check the students' comprehension achievement in this research were limited to some reading comprehension skills. They were finding the main idea, stated and implied information and word references in texts.

In addition, in determining the criteria of success for the reading comprehension achievement for this study, the researcher refered to the Minimum Passing Grade Criteria at SMPN 2 Gondanglegi. The students' passing grade for English subject was 65 with the number of students who pass the passing grade is $85 \%$.

The students' motivation was said to be improved when they have a better preparation for attending a class such as bringing their notebooks and the textbooks, doing their homework, paying attention to the classroom situation and knowing the materials to be learnt in the current meeting. In this study, the researcher refers to Dornyei (2005:78) in which he describes a learning orientation/motivation scale and its sample items.

\section{Implementing the Reasearch}

The researcher implemented this research in planned cycles with one of his teacher colleague to be the observer. To support the consistency of the data, especially the qualitative ones, it is 
also important to have more than one implementation (meeting) for one cycle with different themes to be the instructional materials.

In fact, there was more than one cycle in this research because the criteria of success were not achieved after the test given following the end of the first cycle. This research was conducted in four meetings for two cycles with the themes of "Mass Media" for cycle one and "Technology" for cycle 2. In meeting one and two for the cycle one, the sub themes were "Newspaper" and "Television". The sub themes "Light Technology" and "Advanced Technology" were selected for the meeting three and four in the second cycle.

\section{Observing the Reasearch}

During this phase, the teacher and the observer monitored the implementation of the action as it was previously planned. In this phase the data collecting was conducted. The data collecting activity was actually done at the same time as the teaching learning process. The researcher then interpreted the data so that he could understand the effects of the strategy including the handicaps faced during the implementation of the action.

As the characteristic of a qualitative research, the key instrument of this study to collect the data was the researcher himself with observation checklists, field notes, and questionnaires to support the data gathering. Furthermore, an instrument of tests was also used as an quantitative data to confirm the main data of this study.

\section{Reflecting the Research}

In this phase, the researcher made a sharp conclusion based on the data. The most important aspects the researcher needed to pay the attention to were: (1) the appropriateness between the implementing and the planning formulated before, (2) the handicaps that possibly happen during teaching learning process, and (3) the improvement achieved by the students. Furthermore, the main activity in this phase was comparing the result of observing phase to the criteria of success determined before. The result of the reflection was used as information for considering the following action.

\section{RESEARCH FINDINGS}

\section{The Result of the First Cycle}

This section focuses on identifying the effects of the implementation of the strategy compared to the criteria of success in the first cycle. To clearly identify the result of the first cycle, the researcher presented two kinds of data gathered. Firstly, the data concerned with the teaching and learning process, especially the students' reading motivation, which were taken from the observation sheets for the teacher's and students' activities and the field notes during the first and the second meetings; secondly, the data related to the students' learning result on the reading comprehension achievements which were taken from the tests.

From the observation results on teacher's performance at the first meeting based on the observation of the observer, it was found that the implementation of using three phase technique with vocabulary quiz as a pre activity in reading comprehension had fulfilled the expected criteria. The steps done by the teacher during the first meeting of the first cycle indicated that the technique had been implemented well. 
When monitoring the students' performance in the first meeting of the first cycle, it was identified that some students did not bring their textbooks and did not make vocabulary notes on their notebooks. It was also found that some students worked together with their friend in the vocabulary quiz phase regardless of the teacher suggestion that they were not allowed to work together. It was clear that they did not prepare well for the class. In the pre reading phase of the first meeting, it was identified that a few numbers of students did not pay attention to the teacher's explanation/talks. They did not response to the teacher's presence with his media and opening questions to initiate the lesson. In fact, it was uncovered that they did not bring their textbooks with them so that they could not follow the teacher's instructions. In this situation the teacher had reminded them to do the right thing. During whilst and post reading, those students who did not bring their textbooks seemed to have difficulties to go after the teaching and learning procedures. They had to share with his friend for the book when the teacher asked them to work on the tasks.

At the second meeting, the teacher's performance was basically the same as at the first meeting. In this meeting, the students who made a little obstruction to the planned strategy in the first meeting were almost absent. They brought their textbooks, made the vocabulary notes and had some attention to the teacher's presence or talks. There was likely nobody trying to look at his/her friends work in the vocabulary quiz phase. Having the vocabulary quiz as the pre activity, the students interacted more in the pre reading activity. The number of students responding to the teacher's opening questions increased significantly rather than before. There were also more students arguing to their friends' answers.

During whilst and post reading phases in this second meeting, the students worked on their tasks better than in the first meeting. Most of them finished summarizing task based on the text, and answering the comprehension questions just in the right time. Furthermore, the discussions on students' answers on comprehension questions were easier since there were some possible answers from students who were in volunteer proposed the answers. This situation was hardly identified in the preliminary study and the first meeting.

Based on the result of the students' average score of the quiz, it was recognized that there was a tendency that the students' ability to answer the quiz were increasing from meeting one to two of the first cycle. The average score in meeting one is 61.37 and for the meeting two is 69.95. Another on going data from the post reading phase tests showed the improvement of the average scores in which the first meeting average score was 69.6 and the second meeting was 75.7 .

However, there was another important data to be considered, which were taken from a test after the first cycle had been completed. The test was given after two meetings of teaching learning process, and the test questions emphasized in this text included finding the main idea, stated and implied information and also references in the text.

The result of the test showed that the average score of students' comprehension achievement was 61.29 with $32.5 \%$ of the students scored above the minimum criteria. From the calculation, it was found that the lowest grade was 25 and the highest was 100. So, it can be concluded that the students' achievement score did not fulfill the expected criteria which is 65 with $85 \%$ of the students scored at least 65 . Therefore, the teacher decided to make some revisions on certain aspects of the strategy for cycle 2 . The reflection of the first cycle of the actions revealed several aspects which needed revising. 
The first thing to consider was improving the students' reading motivation by intensifying the instructions to make vocabulary notes on the students' notebooks before they came to the reading class. As it was discussed above some students did not even make the vocabulary notes to facilitate them in the quiz so that they had difficulties to follow the class. In fact, it contributed to their low motivation to do the tasks during the reading phases.

The second thing to consider was setting the items of the quiz into two (A and B) during the vocabulary quiz phase so that each student in one desk would have different quiz items. When the students were not dependent to one another, they would prepare for the quiz better. It meant they would develop their background knowledge to prepare for the reading class which would facilitate them in comprehending texts.

\section{The Result of the Second Cycle}

From the observation results of the second cycle on teacher's performance at the first meeting and the second one based on the observation of the observer, it was found that the implementation of the strategy, with the revised steps proposed in the first cycle, had fulfilled the expected criteria. The students' performance was also apparently well since no student obstructed the planned strategy.

In this cycle, the students could simply follow the lesson well.They brought their textbooks, made the vocabulary notes and had enough attention to the teacher's presence or talks. There was likely nobody trying to look at his/her friends work in the vocabulary quiz phase. Having discussion after the vocabulary quiz in the pre reading activity, the students interacted more. The number of students responding to the teacher's opening questions increased significantly rather than before. There were also more students arguing to their friends' answers or statements. Somehow, the atmosphere of the class seemed a little crowded, but still under the teacher's control.

Based on the analysis of the post research questionnaire, it displayed that the students liked to have the vocabulary quiz in the pre activity before an English reading class was started. It was because they felt that the quiz was helpful to the learning process of understanding texts. They believed that their vocabulary mastery had improved due to the quiz so that it facilitated them in understanding texts. The quiz also made the students study before they came to the English class especially when there was a quiz about to be given.

Based on the result of the students' average score of the quiz, it was recognized that there was a tendency that the students' ability to answer the quiz were increasing from meeting one to two of the first cycle. The average score in meeting one is 70.45 and for the meeting two is 71.62. Another on going data from the post reading phase tests showed the improvement of the scores in which the first meeting average score is 80.4 and the second meeting is 82.4 .

The result of the test showed that the average score of students' comprehension achievement was 66.73 with $42 \%$ of the students scored above the minimum criteria. From the calculation, it was found that the lowest grade was 31 and the highest was 100. So, it can be concluded that the students' achievement score had fulfilled the expected criteria which is 65 although only with $42 \%$ of the students scored above 65 .

Based on the result gained in the second cycle, it was further analyzed that the students' reading motivation and their comprehension achievement as a whole were sufficient 
from what were expected. Consequently, it was concluded that this study had fulfilled the criteria set up before; therefore, the researcher decided to stop the action.

\section{DISCUSSION}

\section{Result of the Study and Theoretical Perspective}

Prior to the implementation of using three phase technique with vocabulary quiz as a pre activity in reading comprehension, setting the instructional objective, planning and structuring the tasks were set up. After the objectives were specified, the tasks were structured. Kessler, (1992) said, "The learning experiences that are planned and structured allow learners to have the opportunity to build on what they already know, to have a clear sense of direction, and have enough time to develop their understanding."

Before applying the technique, the teacher paid more attention about determining the vocabularies. He considered the theme and the level of the students. He also had to select the text wisely. Then, he instructed the students to have vocabulary notes in their notebooks every time they had a reading comprehension class; and so, the rewards should be given, in terms of the scores to the result of the quiz, to motivate both the low and high level students.

Pre reading activity, which was begun by asking the students' comprehension on the related topics, was to facilitate students to recall their prior knowledge dealing with the topics discussed. The pre reading segment by discussing general information that the teacher introduced to students, could bring the students to the situation that generated expectations that were useful in anticipating and predicting the content of materials or texts to read. In this study, this fact was supported by the result of questionnaire in which students liked the quiz because it could facilitate their understanding to the text. Furthermore, Burden and Byrd (1999) stated that "Pre reading activities are used to activate the students' prior knowledge and to help motivate students to read. The activities also promote specific skills in students such as defining the purpose of reading, asking questions, making predictions, figuring out the meaning of unfamiliar word, and relating new material to what is already known".

The activities in whilst reading in this study used various techniques for different purposes of reading subskills to be learnt. The skimming technique was intended to help the students to find main idea rapidly. To find specific information from text, the students were trained by using scanning technique to get the answer not only correctly but also fast. As Folse (1993:14) said, "in order to do reading exercises very quickly and very accurately, you must be able to find an answer for a question rapidly."

Next, mind mapping technique was also used to give the students practices to classify ideas/information in a text. The students could determine whether the information in the text belong to the main idea, stated or implied ones. The other activity was summarizing. In this activity, students condensed a text into shorter sentences without sacrificing the essential contents. Here, students were trained to distinguish the main ideas and the supporting details.

The post reading stage was provided with the tasks containing questions, which were required to reinforce the students' understanding about the topics that had been discussed. It was also the time to discuss the answers to strengthen the students' understanding on certain topics. In this study, this phase was used to make the students get used to the understanding of certain types of comprehension questions. 


\section{Results of the Students' Learning Achievement in Reading Comprehension}

The results of the students' learning achievements in reading comprehension throughout the research were characterized into two different types namely the result based on process and based on product.

Based on the result of the students' vocabulary quiz scores and their scores on comprehension exercises during the post reading phases in cycle I and II, there was a tendency that the students' reading performance were increasing. The increase on the students' vocabulary quizzes scores hand in hand with their scores achievement in comprehension exercises during the post reading phases. That was why the researcher considered that the action of cycle 2 was sufficient, and he stopped the action at this cycle.

The students' reading achievement based on product was derived from the result of the students' achievement in doing the tests of reading comprehension at the end of each cycle. There were evidences that the students achievements gradually increased. It was proven by the students' scores in the test (post test) 1 and 2. Since the base of the research criteria of success had been determined, it was necessary to refer to those criteria in determining the success of this study.

Based on the average scores of the students' reading achievement from the test given in the preliminary study until the test after cycle 2 , it was concluded that using three phase technique with vocabulary quiz as a pre activity in reading comprehension gradually and positively increased the students reading comprehension achievement. However, it still needed more time and some improvement to apply such technique effectively.

\section{CONCLUSIONS AND SUGGESTIONS}

The use of three phase technique with vocabulary quiz as a pre activity in reading comprehension class covers four main phases. They are the vocabulary quiz, the pre, whilst and post reading activities. Giving clear and firmed instructions to prepare the quiz and scoring the result of the students' quiz as "reward" could motivate the students. By implementing those four phases, especially with more variations of developing reading skills activities in the whilst reading phase, this study could improve the students' reading performance on their reading motivations and comprehension achievements.In addition, this technique can be an alternative to be implemented in reading classess for English teachers, particularly those whose students have low motivation in learning and have limited vocabularies to access a text.

\section{REFERENCES}

Agustien, Helena I.R. 2006. Landasan Filosofis - Teoritis Pendidikan Bahasa Inggris (Materi Diklat Tindak Lanjut Uji Kompetensi Guru SMP). Surabaya: LPMP Jatim

Bates, Nina. 2005. Real Time 3 (Student's Book). Jakarta: PT Phibeta Aneka Gama

Burden, Paul R. And Byrd, David M. 1999. Methods for Effective Teaching. Boston: Allyn \& Bacon

Djuharie, Otong Setiawan. 2007. Genre. Dilengkapi 700 Soal Uji Pemahaman.

Bandung: CV. Yrama Widya 
Dornyei, Zoltan. 2005. The Psychology of the Language Learner - Individual Differences in Second Language Acquisition. New Jersey: Lawrence Erlbaum Associates, Inc

Hanafi. 2004. Speed Reading Techniques to Improve EFL Students' Reading Comprehension. Thesis (Unpublished). Unpublished Thesis. Malang: Graduate Program, State University of Malang.

Hudson, Thom. 2007. Teaching Second Language Reading. Oxford: Oxford University Press

Folse, Keith S. 1993. Intermediate Reading Practice. Jakarta Barat: Binarupa Aksara

Kessler, Carolyn. 1992. Cooperative Language Learning. Englewood Cliffs, New Jersey: Prentice Hall Regents

Kweldju, Siusana. 2002. Pengajaran Bahasa Inggris Berbasis Leksikon. (Pidato Pengukuhan Guru Besar dalam Bidang Kosakata). Malang: Universitas Negeri Malang

Mathison, Carla. 1999. Activating Students' Interest in Content Area Reading. Journal of Reading. December 1999. pp 170-175

Sugiono, Johny. 2000. Vocabulary Expansion within a Reading Comprehension Course. Thesis (Unpublished). Malang: Graduate Program, State University Of Malang. 